\title{
Praktik Pendisiplinan Tubuh dan Resistensi Masyarakat Pelaku Usaha Wisata Bahari Pada Masa Pandemi Covid-19 di Pulau Derawan, Kabupaten Berau Kalimantan Timur
}

\author{
Ahmad Hidayah \\ Universitas Gadjah Mada \\ Email: ahmad.hidayah@mail.ugm.ac.id
}

\begin{abstract}
Abstrak
Penelitian ini bertujuan untuk menjelaskan praktik pendisiplinan tubuh (biopolitik) terhadap masyarakat pelaku usaha wisata bahari, serta resistensi yang dilakukan oleh masyarakat pelaku usaha wisata bahari di Pulau Derawan ketika pandemi Covid-19. Pegumpulan data dalam penelitian ini menggunakan metode kualitatif, dengan teori biopolitik dari Michael Foucault dan teori resistensi dari James C. Scott untuk menganalisis temuan penelitian. Hasil penelitian menunjukkan bahwa selama pandemi Covid-19 Pemerintah Kabupaten Berau dan Pemerintah Kampung Pulau Derawan mendisiplinkan tubuh para pekerja dan pelaku usaha wisata bahari di Pulau Derawan dengan cara membuat regulasi penutupan sementara objek wisata Pulau Derawan. Selanjutnya tindakan perlawanan (resistensi) dilakukan oleh pelaku usaha wisata bahari di Pulau Derawan karena keterlambatan respon pihak Pemerintah Kampung Pulau Derawan mengenai pembukaan kembali destinasi wisata pada era normal baru. Bentuk resistensi pelaku usaha wisata bahari di Pulau Derawan adalah menyampaikan aspirasi/ teguran terhadap Pemerintah Kampung Pulau Derawan sebagai pengambil kebijakan serta mensiasati regulasi protokol kesehatan bagi wisatawan untuk memasuki Pulau Derawan. Resistensi yang dilakukan ini adalah bentuk perlawanan pelaku usaha wisata terhadap regulasi pemerintah, sekaligus cara mereka bertahan dalam menanggapi kesulitan yang mereka hadapi pada masa pandemi Covid 19.
\end{abstract}

\section{Kata kunci: Covid 19, Pelaku Usaha, Pendisiplinan Tubuh, Resistensi, Wisata Bahari}

\begin{abstract}
This study aims to explain the practice of body discipline (biopolitics) against the marine tourism business community, as well as the resistance carried out by the marine tourism business community on Derawan Island during the Covid-19 pandemic. Data collection in this study used a qualitative method, with the biopolitical theory of Michael Foucault and the theory of resistance from James C. Scott to analyze the research findings. The results showed that during the Covid-19 pandemic, the Berau Regency Government and the Derawan Island Village Government disciplined the bodies of workers and marine tourism business actors on Derawan Island by making regulations for the temporary closure of Derawan Island tourist attractions. Furthermore, the action of resistance was carried out by marine tourism business actors on Derawan Island due to the delay in the response of the Derawan Island Village Government regarding the reopening of tourist destinations in the new normal era. The form of resistance of marine tourism business actors on Derawan Island is to convey aspirations/ rebuke to the Derawan Island Village Government as a policy maker and to anticipate health protocol regulations for tourists to enter Derawan Island. This resistance is a form of resistance by tourism business actors to government regulations, as well as their way of surviving in responding to the difficulties they face during the Covid 19 pandemic.
\end{abstract}

Keyword: Body Discipline, Business Actors, Covid 19, Marine Tourism, Resistance

Jurnal Socius: Journal of Sociology Research and Education Vol. 8, No. 2, Th. 2021 
Ahmad Hidayah

Praktik Pendisiplinan Tubuh dan Resistensi Masyarakat Pelaku Usaha Wisata Bahari Pada Masa Pandemi Covid-19 di Pulau Derawan Kabupaten Berau Kalimantan Timur

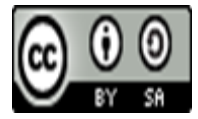

Received: May 18, 2021

Revised: December 30, 2021

Available Online: December 31, 2021

\section{Pendahuluan}

Pandemi Covid-19 menyebabkan banyak permasalahan bagi masyarakat. Sejak awal kemunculannya di Wuhan China pada bulan Desember 2019 telah melahirkan anomali dan distorsi di berbagai negara. Sejak diumumkan kasus pertama di Indonesia pada 2 Maret 2020, hingga tanggal 07 April 2021 jumlah total kasus pasien yang positif Covid-19 telah mencapai 1.547.376 jiwa dimana 113.570 kasus aktif yang masih menjalani perawatan (Anwar, 2021). Pandemi Covid19 memberikan dampak yang begitu besar dalam kehidupan masyarakat. Salah satu sektor industri yang terkena dampak adalah sektor industri pariwisata (Bakar \& Rosbi, 2020; Gunagama et al., 2020; Hoque et al., 2020). Khusus di Indonesia dampak pandemi Covid-19 terhadap industri pariwisata dapat dilihat dari laporan BPS yang menyatakan pada bulan Maret 2020 terjadi penurunan kunjungan wisatawan mancanegara sebesar 64,11\% dibandingkan dengan data pada bulan Maret 2019 (Aditya, 2020).

Sebelum pandemi Covid-19 menyerang, banyak studi yang menyatakan bahwa industri pariwisata merupakan sektor perekonomian yang menjanjikan pertumbuhan ekonomi bagi sebuah negara (Amortegui et al., 2019; Indraningsih, 2019; Pillai, 2011; Pitana \& Diarta, 2009; Primadany et al., 2013; Setiawan, 2015; Sofronov, 2018). Bahkan, sektor pariwisata kini dijadikan salah satu sektor unggulan sebagai solusi menipisnya sumber mineral (sektor industri sumber daya alam mineral) (Nugroho, 1997). Melemahnya sektor industri pariwisata di Indonesia disebabkan oleh peraturan yang dikeluarkan oleh Pemerintah Indonesia melalui Peraturan Pemerintah Nomor.21 Tahun 2020 tentang Pembatasan Sosial Berskala Besar Dalam Rangka Percepatan Penanganan Corona Virus Disease 2019 (Covid-19). Peraturan Pemerintah tersebut dibentuk guna menghentikan penyebaran 2019 Coronavirus Disease 2019 (Covid-19). Berdasarkan hal tersebut, maka hampir semua kegiatan masyarakat Indonesia (di luar rumah) terpaksa harus dihentikan termasuk aktivitas pariwisata.

Berdasarkan pernyataan di atas, realita yang terjadi pada saat pandemi Covid-19 berlangsung menyebabkan segala aktivitas kepariwisataan terpaksa harus dihentikan. Kondisi tersebut juga terjadi di objek wisata bahari Pulau Derawan. Pulau Derawan merupakan salah satu objek wisata bahari andalan di Kabupaten Berau yang terletak di Kecamatan Pulau Derawan, Kabupaten Berau, Kalimantan Timur. Pulau Derawan memiliki potensi keindahan alam berupa pantai pasir putih bersih, taman bawah laut yang indah serta banyaknya Penyu Hijau dan Penyu Sisik yang sering berada di pinggir pantai. Berdasarkan hal tersebut Pulau Derawan layak dijadikan objek wisata andalan di Kabupaten Berau (Hidayah, 2021). Secara geografis Pulau Derawan berada di sebelah selatan Selat Makassar dimana selat tersebut terhubung langsung dengan perairan Sulawesi dan Jawa dan di sebelah timur Pulau Kalimantan. Pulau ini memiliki luas wilayah sebesar 44,60 ha.

Pulau Derawan merupakan wilayah dengan bentuk topografi kepulauan, berdasarkan kondisi tersebut maka masyarakat Pulau Derawan banyak yang memanfaatkan potensi bentuk topografi Pulau Derawan untuk perikanan dan pariwisata. Pada tahun 2020 penduduk di Pulau Derawan sebanyak 1.560 jiwa (400 KK) (Pemerintah Kampung Pulau Derawan, 2020). Perda Provinsi Kalimantan Timur Nomor 14 Tahun 2008, tentang Rencana Induk Pengembangan Pariwisata

Jurnal Socius: Journal of Sociology Research and Education Vol. 8, No. 2, Th. 2021 
Daerah Provinsi Kalimantan Timur menjadikan Pulau Derawan sebagai wilayah yang diprogramkan untuk menjadi kawasan pengembangkan pariwisata. Persebaran tutupan terumbu karang keras di Pulau Derawan sebesar rata-rata 17,41\%. Selain itu, potensi lain dari Pulau Derawan adalah memiliki persebaran karang hidup sebesar 27,78\%. Pulau Derawan juga merupakan habitat asli bagi Penyu Hijau dan Penyu Sisik. Kedua jenis penyu tersebut termasuk jenis penyu langka (terancam punah) (Mujiono, 2018).

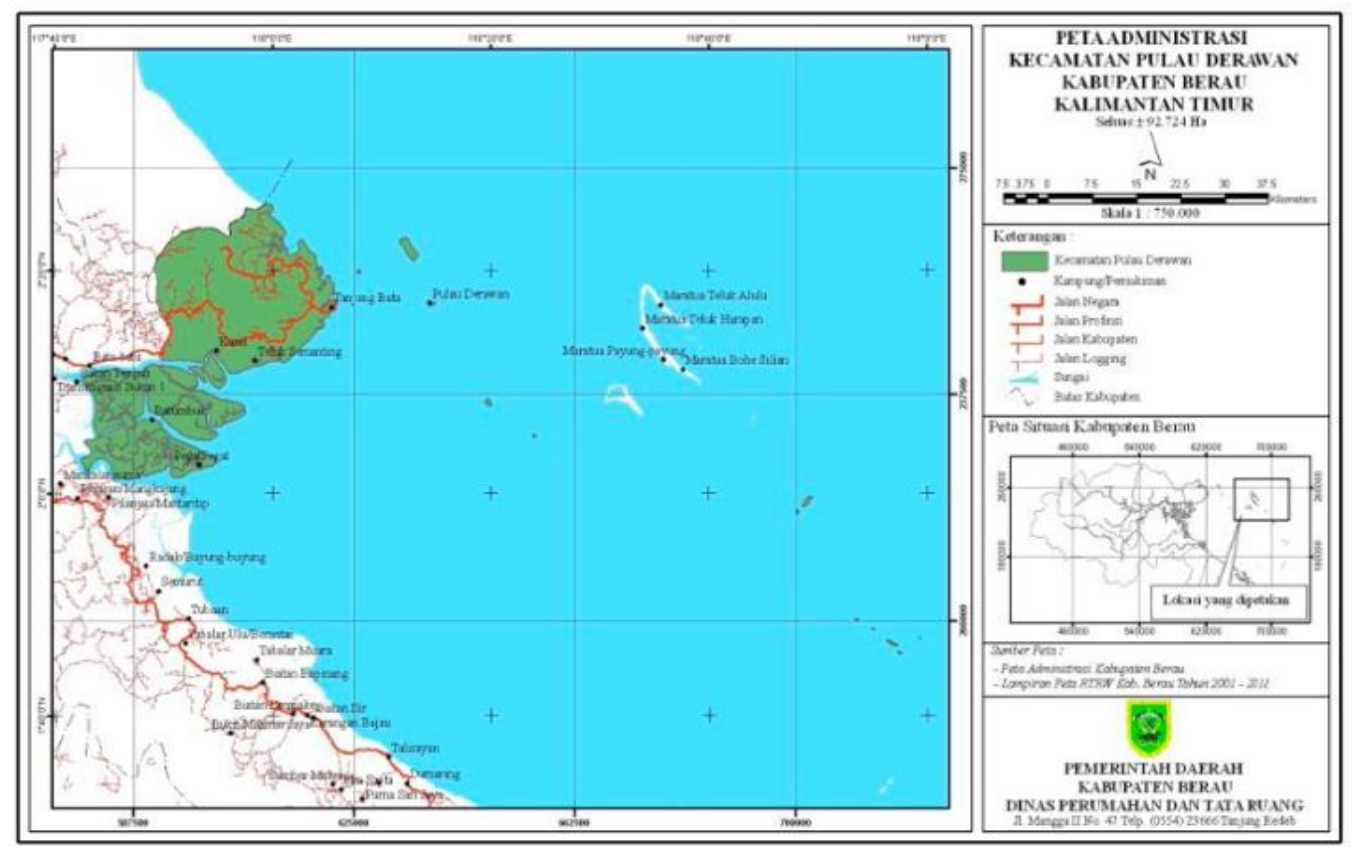

Gambar 1. Peta Kecamatan Pulau Derawan

Sumber: Pemerintah Kabupaten Berau, 2018

Semenjak pandemi Covid-19, banyak dinamika yang terjadi di Pulau Derawan. Aktivitas pariwisata yang biasanya menjadi aktivitas sehari-sehari masyarakat di sana terpaksa harus dihentikan demi memutus rantai penyebaran virus Covid-19. Pekerja dan pelaku usaha wisata di Pulau Derawan turut serta menjalankan instruksi dari pemerintah mengenai pandemi Covid-19. Tindakan tersebut merupakan bentuk praktik biopolitik (pendisiplinan tubuh) yang dilakukan oleh pihak Pemerintah terhadap masyarakat dengan tujuan agar dapat mempercepat pemutusan rantai penyebaran virus Covid-19. Pada awal masa pandemi Covid-19 berlangsung, praktik biopolitik tersebut diterima dan dilaksanakan dengan baik oleh para pekerja dan pelaku usaha wisata bahari di Pulau Derawan. Namun, dikarenakan keterlambatan respon dari pihak Pemerintah Kampung Pulau Derawan mengenai pembukaan kembali destinasi wisata Pulau Derawan di era new normal maka hal tersebut menimbulkan polemik bagi masyarakat Pulau Derawan yang bekerja dan memiliki usaha di bidang pariwisata bahari. Oleh sebab itu, pelaku usaha wisata bahari di Pulau Derawan melakukan perlawanan (resistensi) terhadap kebijakan pemerintah karena menjadi pihak yang dirugikan atas kebijakan tersebut. Berdasarkan hal tersebut maka tujuan penelitian ini adalah untuk menjelaskan praktik pendisiplinan tubuh (biopolitik) terhadap masyarakat pelaku usaha

Jurnal Socius: Journal of Sociology Research and Education Vol. 8, No. 2, Th. 2021 
wisata bahari, serta resistensi yang dilakukan oleh masyarakat pelaku usaha wisata bahari di Pulau Derawan ketika pandemi Covid-19.

Beberapa studi terdahulu membahas mengenai pandemi Covid-19 telah banyak dilakukan. Studi pertama adalah studi yang dilakukan oleh Walakula (2020) pada artikelnya yang berjudul "Analisis Eksistensi Pariwisata Indonesia di Tengah Situasi Pandemi Corona Virus Disease (Covid-19)". Berdasarkan studi tersebut, diperoleh fakta bahwa sektor pariwisata Indonesia mengalami permasalahan yang sangat serius karena adanya wabah virus corona (Covid-19) (Walakula, 2020). Hampir sama dengan studi pertama, studi kedua yang dilakukan oleh Budiyanti (2020) juga menyatakan bahwa bahwa dampak dari adanya pandemi Covid-19 menyebabkan penurunan kunjungan wisatawan asing ke Indonesia (Budiyanti, 2020). Studi ketiga yang membahas tentang hal tersebut adalah studi yang dilakukan oleh Ayittey (2020), menurutnya pandemi Covid-19 memberikan dampak yang sangat besar pada perdagangan, pariwisata dan perdagangan. Studi keempat adalah studi yang dilakukan oleh Herdiana (2020). Studi ini dilakukan di Kota Bandung, studi ini menyatakan bahwa pariwisata merupakan salah satu sektor yang paling terdampak wabah Covid-19 di Kota Bandung.

Hampir sama dengan studi sebelumnya, studi kelima ini membahas mengenai dampak dari pandemi Covid-19 di China. China merupakan negara awal yang terjangkit pandemi Covid-19. Berdasarkan hal tersebut maka pandemi Covid-19 memberikan dampak yang besar bagi industri pariwisata China karena selama pandemi Covid-19 menyerang mereka harus membuat kebijakan lockdown (Hoque et al., 2020). Studi ke enam yang digunakan pada penelitian ini adalah studi mengenai potensi objek wisata bahari di Pulau Derawan yang dilakukan oleh Mujiono (2018). Merujuk pada studi tersebut, Pulau Derawan memiliki daya tarik sebagai objek wisata bahari karena terletak di wilayah laut segitiga koral dunia. Oleh sebab itu keindahan bawah laut Pulau Derawan sudah tidak diragukan lagi. Selain itu, sebagai wilayah objek wisata Pulau Derawan juga memiliki fasilitas akomodasi yang lengkap bagi para wisatawan yang ingin berkunjung (Mujiono, 2018).

Berbagai studi di atas menjelaskan bahwa pandemi Covid-19 berdampak pada sektor pariwisata, terutama pada perekonomian masyarakat pelaku usaha dalam bidang pariwisata. Oleh sebab itu diperlukan upaya pemulihan secara komprehensif dan berkelanjutan (Herdiana, 2020). Berbeda dengan studi-studi terdahulu yang terbatas pada pembahasan mengenai pengaruh pandemi Covid-19 terhadap industri pariwisata, penelitian ini memfokuskan pada kajian tentang praktik pendisiplinan tubuh para pelaku usaha pariwisata, dalam rangka meminimalisasi dampak pandemi Covid-19 di daerah tujuan wisata serta bentuk resistensi yang dilakukan pelaku usaha wisata, agar tetap dapat bertahan menghadapi dampak pandemi Covid-19. Kebaruan penelitian ini semakin diperkuat karena membingkai temuan penelitian dengan menggunakan teori biopolitik dari Michael Foucault dan teori resistensi dari James C. Scott, sebuah kajian yang masih jarang dilakukan oleh peneliti sebelumnya. Atas dasar itu maka penelitian ini memiliki nilai originalitas serta kontribusi terutama pada studi sosiologi pariwisata dan kesehatan.

\section{Metode Penelitian}

Artikel ini menggunakan metode penelitian kualitatif, untuk mengidentifikasi realita sosial yang terjadi serta mencoba menafsirkan makna-makna yang dijelaskan oleh masyarakat (Creswell, 2007). Penelitian ini dilakukan di Pulau Derawan, Kabupaten Berau, Kalimantan Timur dengan tujuan agar dapat mengidentifikasi dan menafsirkan bagaimana praktik pendisplinan tubuh serta

Jurnal Socius: Journal of Sociology Research and Education Vol. 8, No. 2, Th. 2021 
resistensi masyarakat Pulau Derawan bekerja dan memiliki usaha bidang pariwisata bahari. Informan dalam penelitian ini adalah pekerja dan pemilik usaha bidang pariwisata bahari di Pulau Derawan, Kabupaten Berau, Kalimantan Timur. Alasan peneliti memilih informan tersebut karena tipe informan tersebut sesuai dengan kriteria informan yang dibutuhkan pada penelitian ini sehingga dapat memberikan pernyataan/ data yang sesuai dengan kebutuhan penelitian ini.

Sumber data pada penelitian ini sumber data primer yang diperoleh dari hasil wawancara dan observasi yang dilakukan dengan cara berkunjung langsung ke Pulau Derawan dan menyaksikan bagaimana masyarakat yang termasuk pekerja dan pemilik usaha bidang pariwisata bahari di Pulau Derawan, Kabupaten Berau, Kalimantan Timur mentaati peraturan mengenai Covid-19 yang ditetapkan pemerintah. Teknik pemilihan informan pada penelitian ini menggunakan teknik purposive sampling dan snowball sampling. Kedua teknik tersebut digunakan karena penelitian ini harus mendapatkan data dari informan yang sesuai dengan kriteria untuk penelitian ini (purposive sampling) dan peneliti banyak mendapatkan informan lain berdasarkan rekomendasi dari informan kunci pada penelitian ini (snowball sampling). Analisis data hasil penelitian menggunakan model interactive analysis dari Milles dan Hurberman, melalui tiga tahap penelitian yaitu; (1) reduksi data, (2) penyajian data, dan (3) penarikan kesimpulan/ verifikasi data (Miles \& Huberman, 1994).

\section{Hasil dan Pembahasan}

\section{Praktik Pendisiplinan Tubuh (Biopolitik) Selama Pandemi COVID-19 Berlangsung di Pulau Derawan}

Pandemi Covid-19 melanda Indonesia secara masif menyebabkan perlunya tindakantindakan yang cepat dan tepat untuk menanggulanginya. Pandemi Covid-19 bisa menyebar ke seluruh pelosok Indonesia dalam waktu yang cepat. Hal tersebut disebabkan virus ini dapat menyebar melalui kegiatan secara fisik yang berdekatan antar sesama manusia. Berdasarkan hal tersebut maka dibutuhkan penanganan yang serius bagi Pemerintah Indonesia untuk mengatasai permasalahan ini. Melalui Peraturan Pemerintah Nomor. 21 tahun 2020, pemerintah menerapkan Pembatasan Sosial Berskala Besar (PSBB) yang berujung aktifitas dan interaksi masyarakat kemudian dibatasi sebagai langkah prefentif memutus rantai penyebaran Covid-19 (Almuttaqi, 2020; Syafrida \& Hartati, 2020). Khusus di Kabupaten Berau sendiri Pemkab Berau juga mengeluarkan Perda Surat Edaran Bupati Berau Nomor. 551/210/Dishub-Bru/2020 Tanggal 30 Maret 2020 Tentang Pembatasan Penerbangan Niaga Berjadwal di Kabupaten Berau. Kedua, Surat Edaran Kepala Dinas Kebudayaan dan Pariwisata Kabupaten Berau No. 551/209/DishubBru/2020 Tanggal 30 Maret 2020 Tentang Penyaringan dan Pembatasan Semua Akses Masuk Kendaraan Darat dan Air Angkutan Orang dari Dalam dan Keluar Kabupaten Berau dan yang ketiga adalah Surat Edaran Bupati Berau Nomor. 551/013/Dishub.III.1/IV/2020 Tanggal 14 April 2020 tentang Penyaringan dan Pembatasan Orang Masuk Wilayah Kabupaten Berau.

Berdasarkan Perda tersebut, segala aktivitas kepariwisataan di Kabupaten Berau terpaksa harus dihentikan. Hal ini dilakukan sebagai bentuk kepatuhan masyarakat dan pelaku usaha terhadap peraturan pemerintah, untuk menimalisasi dampak yang ditimbulkan oleh pandemi Covid-19. Mengaitkan beberapa Perda dan realita yang terjadi tersebut dengan apa yang dikemukakan oleh Michael Foucault maka dapat disimpulkan bahwa Peraturan Daerah yang ditujukan untuk penghentian aktivitas kepariwisataan merupakan bentuk praktik bioplotik atau pendisiplinan tubuh. Foucault menyatakan bahwa politik tidak hanya mengenai upaya untuk

Jurnal Socius: Journal of Sociology Research and Education Vol. 8, No. 2, Th. 2021 
mendapatkan jabatan penting, tetapi lebih dari itu politik juga merupakan penataan pola hidup manusia karena Foucault melihat bahwasanya biopolitik akan menjadi persoalan utama di masa depan karena persoalan dunia yang semakin rumit diikuti peningkatan populasi manusia. Oleh sebab itu populasi manusia perlu dipantau, dioptimalisasi, dan disiplinkan.

Pandemi Covid-19 yang membutuhkan peran dari Pemerintah Indonesia, dalam hal ini Pemerintah Indonesia mempraktekkan pendisiplinan tubuh terhadap masyarakatnya agar dapat mempercepat pemutusan rantai penyebaran virus Covid-19. Pandemi Covid-19 menuntut reaksi yang cepat dan masif. Satu-satunya kekuatan yang mampu melakukan praktik pendisipilan tubuh pada saat pandemi Covid-19 berlangsung adalah negara. Pada konteks ini praktik pendisiplinan tubuh dilakukan pihak Pemerintah Kabupaten Berau mengenai pembatasan dan penutupan kegiatan pariwisata bahari di Pulau Derawan.

Pihak Pemerintah Kampung Pulau Derawan melaksanakan praktik pendisiplinan tubuh terhadap pekerja dan pelaku usaha dengan cara menutup akses masuk dan keluar Pulau Derawan selama masa pandemi Covid-19. Tindakan tersebut sebagai wujud tindak lanjut dari Peraturan Pemerintah Indonesia dan Kabupaten Berau mengenai pembatasan kegiatan kepariwsataan. Realita tersebut sesuai dengan konsep dari biopolitik yang menyatakan bahwa wujud nyata dari biopolitik adalah kekuasaan pemerintah yang dilakukan dengan cara memantau, membujuk, mendorong, mengontrol dan mengkoordinasikan power yang berada pada negara (Burchell et al., 1991). Dalam hal ini meskipun para pekerja dan pelaku usaha di bidang pariwisata bahari di Kabupaten Berau mengalami kerugian karena regulasi tersebut, mereka tetap harus mengikuti regulasi tersebut karena pada dasarnya pemerintah memiliki kekuasaan untuk mengatur warganya terutama pada masa pandemi ini. Dalam konteks ini biopolitik terlihat jelas dari cara dan strategi yang dilakukan oleh negara untuk mengontrol aspek tubuh warganya,yang sejatinya adalah hak privat masing-masing warganegara, namun dalam hal ini negara memiliki kuasa atas tubuh warganya, yang dikontrol melalui berbagai kebijakan.

Demikianlah pemaparan mengenai praktik pendisiplinan tubuh (biopolitik) yang terjadi pada masa pandemi Covid-19 di Pulau Derawan, Kabupaten Berau. Pekerja dan pelaku usaha dipaksa untuk mengikuti regulasi yang termanifestasi sebagai bentuk praktik pendisiplinan tubuh. Praktik biopolitik pada konteks ini bertujuan untuk memutus rantai penyebaran virus Covid-19 melalui aspek kegiatan pariwisata. Hal ini karena mereka menyadari bahwa aktivitas pariwisata salah satu aspek yang dapat memperparah penyebaran Covid-19 jika protokol kesehatan tidak dilaksanakan sesuai aturan.

\section{Resistensi Terhadap Praktik Pendisiplinan Tubuh Bagi Pekerja dan Pelaku Usaha Wisata di Pulau Derawan}

Selama pandemi Covid-19 dilaporkan telah terjadi penurunan drastis terhadap kunjungan pariwisata di Kabupaten Berau. Pada bulan Januari tahun 2020, sebanyak 67 wisatawan asing dan 25.887 wisatawan lokal yang berkunjung, namun pada bulan Februari tahun 2020 hanya sebanyak 13 wisatawan asing dan 2.800 wisatawan lokal yang berkunjung ke Pulau Derawan (ProKaltim, 2020). Pada awal pandemi Covid-19 para pekerja dan pelaku usaha wisata bahari di Pulau Derawan, Kabupaten Berau bersedia dan terus menjalani regulasi yang dibuat oleh Pemerintah Kabupaten Berau demi memutus rantai penyebaran virus Covid-19 di Kabupaten Berau. Masa tersebut merupakan masa yang sulit bagi mereka karena secara langsung menutup sumber mata pencaharian mereka.

Jurnal Socius: Journal of Sociology Research and Education Vol. 8, No. 2, Th. 2021 
James C. Scott mendefinisikan resistensi/ perlawanan sebagai bentuk tindakan rasional bagi kaum atau kelompok subordinant sebagai upaya pengurangan/ penolakan terhadap kelompok superdinant. Pada konteks ini pihak Pemerintah Kampung Pulau Derawan tergolong sebagai kelompok superdinant dan para pelaku usaha tergolong sebagai kelompok subordinant. Penyebab tindakan resistensi yang dilakukan para pengusaha di bidang wisata bahari Pulau Derawan adalah ketidakpastian dari pihak Pemerintah Kampung mengenai pembukaan kembali destinasi objek wisata Pulau Derawan padahal dari Pemerintah Pusat dan Pemerintah Kabupaten Berau telah mengeluarkan regulasi mengenai pembukaan kembali objek wisata di era new normal. Sebagaimana yang diungkapkan oleh HG berikut ini;

"Kalau Agustus itu sebenarnya per tanggal 1 Agustus sudah dibuka untuk Kaltim dan Kaltara sesuai dengan peraturan Bupati, ada edaran kan tentang pembukaan kembali objek wisata pada bulan Agustus. Hanya saja kan tetap kembali ke pemerintahan Kampung (Pulau Derawan). Namun, Pemerintah Kampung itu pada saat itu belum merespon Surat Edaran itu, akhirnya kita terlambat buka objek wisata di sini sampai dengan tanggal 18 Agustus. Nah, tapi untuk warga Kaltim bisa dengan menggunakan syarat yang menyesuaikan protokol kesehatan Covid-19. Nah kami dari pelaku usaha pariwisata seperti perhotelan, guide, speed boat itu mendorong Pemerintah Kampung (Pulau Derawan ini) untuk merespon surat itu. Kami memertanyakan respon mereka terhadap surat itu bagaimana? Apakah ini tetap ditutup atau dibuka, jangan surat edaran itu didiamkan kan. Akhirnya jadi polemik itu mas di masyarakat." (Wawancara, 17 Desember 2020).

Hal yang sama juga terungkap dari AM, menurutnya;

"Nah, waktu itu kan sudah jelas bahwa di Surat Edaran itu dari bulan ini ke ini dibuka untuk wilayah Kaltim, dari bulan ini ke ini dibuka untuk Utara, dan bulan ini ke ini untuk Nusantara. Tapi kita masih agak simpang siur. Simpang siurnya itu kita masih bertanya-tanya sebenarnya ini benar sudah boleh atau tidak. Sedangkan pihak sini masih menolak." (Waancara, 16 Desember 2020).

Berdasarkan kutipan wawancara tersebut dapat disimpulkan bahwa karena keterlambatan respon dari Pemerintah Kampung Pulau Derawan mengenai kebijakan yang telah dibuat, akhirnya terjadi polemik bagi para pelaku usaha wisata di Pulau Derawan. Berbagai perlawanan dilakukan oleh para pelaku usaha untuk meminta kejelasan dari pihak pembuat kebijakan. Perlawanan ini adalah sebuah cara untuk tetap resisten, menghadapi berbagai dampak yang ditimbulkan oleh kebijakan. Perlawanan yang dilakukan oleh pelaku usaha terlihat dalam berbagai bentuk, diantaranya adalah a) memberikan teguran dan protes secara langsung terhadap pihak Pemerintah Kampung Pulau Derawan serta b) memainkan aturan mengenai protokol kesehatan.

Protes terhadap pemerintah dilakukan dengan cara mempertanyakan dan meminta pihak Pemerintah Kampung Pulau Derawan untuk segera menindaklanjuti Surat Edaran yang telah disebarkan tersebut. Hal ini karena mereka merasa dirugikan karena implementasi aturan dalam membuka kembali Pulau Derawan tidak dilaksanakan sebagaimana mestinya. TM sebagai satu salah satu dari Pihak Kecamatan Pulau Derawan pun membenarkan kondisi tersebut, berikut kutipan wawancaranya:

Jurnal Socins: Journal of Sociology Research and Education Vol. 8, No. 2, Th. 2021 
"Dulu itu Kepala Kampung Pulau Derawan itu masih ragu-ragu untuk membuka kembali Pulau Derawan itu setelah lama ditutup. Padahal sudah ada surat edaran dari Bupati itu kalau sudah boleh dibuka asalkan mengikuti protokol kesehatan. Jadi pas awal-awal bulan Agustus itu saya ikut rapat via zoom dengan pihak Pemerintah Kampung Pulau Derawan dan masyarakat di sana tentang pembukaan kembali objek wisata Pulau Derawan. Saya jelaskan pelan-pelan bagaimana konsep new normal itu. Nah setelah itu baru pelan-pelan Pihak Pemerintah Pulau Derawan itu mau membuka kembali Pulau Derawan untuk wiatawan" (Wawancara, 11 Desember 2020).

Selain itu, bentuk perlawanan atau resistensi yang dilakukan pelaku usaha wisata bahari di Pulau Derawan adalah dengan cara memainkan aturan mengenai protokol kesehatan. Mereka tetap membawa/ mengizinkan wisatawan masuk, meski tidak dilengkapi dengan bukti pelaksanaan protokol kesehatan. Seperti mensiasati waktu masuk lokasi wisata, diluar kontrol pihak yang berwenang. Tindakan tersebut dilakukan sebagai strategi agar tetap dapat mendatangkan tamu/wisatawan tanpa harus mengikuti peraturan yang "ribet" menurut perspektif mereka. Hal ini terungkap dari HG yang menyatakan;

"Iya mas. Jadi terpaksa kita ngikut. Saya aja sendiri mas pada saat awal-awal itu kan posko di dermaga itu kalau kita bawa tamu masuk ke sini harus buat rapid apalah segala itu. Jadi saya akali dengan cara saya bawa masuk tamu ke sini malam hari. Saya bawa putar dulu tamu itu ke Maratua, jadi seolah itu orang dari Maratua baru ke Derawan. Pernah di sini digrebek sama mereka, tapi yaudah gitu-gitu aja."

(Wawancara, 17 Desember 2020).

Berdasarkan kutipan wawancara tersebut dapat dilihat bagaimana bentuk resistensi yang dilakukan oleh pelaku usaha wisata bahari di Pulau Derawan. Salah satu bentuk resistensi dilakukan dengan cara mensiasati aturan yang telah ditetapkan oleh pemerintah. Pelaku usaha sendiri yang terpaksa melakukan pelanggaran protokol kesehatan, sebegai syarat memasuki lokasi wisata, agar mereka tetap bisa menerima kunjungan wisatawan. Hal ini adalah sebuah bentuk agar mereka tetap resisten secara ekonomi ditengah ketatnya aturan dalam aktivitas pariwisata.

Realita di atas sesuai dengan apa yang dikemukakan oleh Scott (2000) bahwa sejatinya akan selalu ada tindakan resistensi (perlawanan) yang dilakukan kaum subordinant terhadap perilaku eksplotasi yang dilakukan oleh kelompok kuat (Scott, 2000). Resistensi ini dilakukan agar mereka tetap bisa mempertahankan diri dari berbagai ancaman yang muncul dari lingkungan, meskipun melanggar berbagai aturan yang telah ditetapkan.

Demikianlah pemaparan terkait resistensi yang dilakukan oleh pelaku usaha wisata bahari di Pulau Derawan, Kabupaten Berau selama masa pandemi Covid-19 berlangsung. Tindakan tersebut dilakukan dengan cara menegur secara langsung pihak Pemerintah Kampung Pulau Derawan dan mensiasati aturan-aturan yang telah ditetapkan. Tindakan tersebut merupakan bentuk perlawanan yang dilakukan sebagai akibat polemik yang disebabkan oleh pandemi Covid-19, dengan tujuan agar pelaku usaha wisata tetap bisa resisten menghadapa berbagai dampak yang ditimbulkan oleh pandemi Covid-19.

\section{Pendisiplinan Tubuh (Biopolitik) dalam Perspektif Michael Foucault dan Resistensi Oleh} James C. Scott

Jurnal Socins: Journal of Sociology Research and Education Vol. 8, No. 2, Th. 2021 


\section{Ahmad Hidayah \\ Praktik Pendisiplinan Tubuh dan Resistensi Masyarakat Pelaku Usaha Wisata Bahari Pada Masa Pandemi Covid-19 di Pulau Derawan Kabupaten Berau Kalimantan Timur}

Michael Foucault (2008) memberikan pemahaman yang mendalam dalam memberikan dasar pemahaman mengenai bagaimana terbentuknya warga sebagai sebuah konsep politik. Berdasarkan hal tersebut maka pertama-tama Foucault memberikan pertanyaan mengenai siapa itu warga dan dipahami ke dalam pertanyaan mengenai bagaimana teknologi kekuasaan bekerja dalam sejarah dalam membentuk siapa itu warga (Robert \& Tobi, 2004). Foucault menyatakan bahwa apabila ingin memahami kekuasaan kita tidak bisa mengajukan pertanyaan apa itu kekuasaan atau siapa yang memiliki kekuasaan serta dari mana sumber kekuasaan? Bagi Foucault cara yang benar memahami kekuasaan harus melalui proses mengajukan pertanyaan bagaimana kekuasaan beroperasi atau dengan cara apa kekuasaan itu dioperasikan (Foucault, 2008).

Foucault (2008) dalam bukunya yang berjudul "The Birth of Biopolitics" memperkenalkan teori mengenai pendisiplinan tubuh atau yang biasa dikenal sebagai "biopolitik". Biopolitik identik pada pola/ bentuk pemerintahan yang khas karena regulasi-regulasi yang dilahirkan melalui proses historis. Wujud nyata dari biopolitik adalah kekuasaan pemerintah yang dilakukan dengan cara memantau, membujuk, mendorong, mengontrol dan mengkoordinasikan power yang berada pada negara (Burchell et al., 1991).

Berdasarkan pemaparan di atas dapat disimpulkan bahwa biopolitik menjelaskan mengenai kekuasaan atas kehidupan di mana pendisiplinan tubuh individu dikontrol oleh regulasi populasi (Jessen \& Eggers, 2020). Keterkaitan teori biopolitik terhadap penelitian ini adalah dimana tindakan individu diatur sedemikian rupa oleh regulasi yang dibuat Pemerintah Indonesia selama pandemi Covid-19 berlangsung. Para pekerja dan pelaku usaha wisata bahari di Pulau Derawan dipaksa untuk menutup usaha mereka karena dipaksa untuk mengikuti regulasi (pendisiplinan) yang dilakukan oleh Pemerintah Indonesia dan Pemerintah Kabupaten Berau.

Kedua, James C. Scott mendefinisikan resistensi/ perlawanan sebagai bentuk tindakan rasional bagi kaum atau kelompok subordinant sebagai upaya pengurangan/ penolakan terhadap kelompok superdinant. Scott (2000) menjelaskan bahwa sejatinya akan selalu ada tindakan resistensi (perlawanan) yang dilakukan kaum subordinant terhadap perilaku eksplotasi yang dilakukan oleh kelompok kuat (Scott, 2000). Scott membagi perlawanan tersebut menjadi dua bagian, yaitu: a) Perlawanan Publik atau Terbuka (Public Transcript), perlawanan ini dilakukan dalam bentuk interaksi terbuka antara kelompok subordinant dan kaum superdinant. b) Perlawanan Tersembunyi atau Tertutup (Hidden Trancript), perlawanan ini dilakukan dengan cara-cara yang tidak terlihat secara langsung oleh kelompok superdinant.

Keterkaitan teori resistensi dari James C. Scott terhadap temuan penelitian ini adalah bahwa tindakan resistensi yang dilakukan pekerja dan pelaku usaha bidang pariwisata bahari di Pulau Derawan, Kabupaten Berau dalam menghadapi pandemi Covid-19 adalah bentuk perlawanan mereka terhadap aturan yang tidak berpihak kepada mereka sebagai kelompok subordinant sekaligus cara mereka bertahan mengahadapi dampak yang ditimbulkan oleh Pandemi Covid-19. Masyarakat Pulau Derawan yang termasuk sebagai pekerja dan pelaku usaha bidang pariwisata merespon regulasi mengenai pandemi Covid-19 yang dibuat oleh Pemerintah Indonesia dan Kabupaten Berau ketika regulasi tersebut dianggap tidak berpihak pada keberlanjutan kehidupan mereka. Resistensi dalam hal ini bukan sekedar bentuk perlawanan kepada penguasa, tetapi juga strategi untuk tetap bertahan melanjutkan keberlangsungan kehidupan masyarakat, keluar dari berbagai kesulitan dan ancaman.

Jurnal Socius: Journal of Sociology Research and Education Vol. 8, No. 2, Th. 2021 


\section{Simpulan}

Pandemi Covid-19 menimbulkan polemik yang sangat besar bagi masyarakat Indonesia. Kondisi tersebut menuntut pihak pemerintah harus mengambil langkah cepat dalam dalam penanganan penyebaran virus Covid-19. Pemerintah Kabupaten Berau dan Pemerintah Kampung Pulau Derawan membuat regulasi penutupan sementara objek wisata bahari Pulau Derawan selama masa pandemi Covid-19 berlangsung. Tindakan tersebut merupakan bentuk praktik biopolitik (pendisiplinan tubuh) yang dilakukan oleh pihak pemerintah terhadap masyarakat dengan tujuan agar dapat mempercepat pemutusan rantai penyebaran virus Covid-19. Pada awal masa pandemi Covid-19 berlangsung, praktik biopolitik tersebut diterima dan dilaksanakan dengan baik oleh para pekerja dan pelaku usaha wisata bahari di Pulau Derawan. Namun, dikarenakan keterlambatan respon dari pihak Pemerintah Kampung Pulau Derawan mengenai pembukaan kembali destinasi wisata Pulau Derawan di era new normal, maka hal tersebut menimbulkan polemik bagi masyarakat Pulau Derawan yang bekerja dan memiliki usaha di bidang pariwisata bahari. Oleh sebab itu, pelaku usaha wisata bahari di Pulau Derawan melakukan perlawanan (resistensi) dengan cara; Pertama, memberikan teguran dan aspirasi terhadap Pemerintah Kampung Pulau Derawan agar segera menanggapi aturan baru mengenai pembukaan kembali destinasi wisata Pulau Derawan di era new normal. Kedua, mensiasati regulasi protokol kesehatan dengan cara tidak membawa tamu ke Pelabuhan Kampung Pulau Derawan untuk pengecekan berkas agar dapat memasuki Pulau Derawan dan berlibur di Pulau Derawan, serta masuk Pulau Derawan di malam hari agar lolos dari pengecekan berkas protokol kesehatan. Resistensi yang dilakukan ini adalah bentuk perlawanan pelaku usaha wisata terhadap regulasi pemerintah, sekaligus cara mereka bertahan dalam menanggapi kesulitan yang mereka hadapi pada masa pandemi Covid 19.

\section{Daftar Pustaka}

Aditya, N. R. (2020). Sesuai Prediksi, Jumlah Wisman pada Maret 2020 Turun karena Corona. kompas.com.

Almuttaqi, A. I. (2020). Kekacauan Respons terhadap COVID-19 di Indonesia. The Habibie Center Insights, 1(13), 1-7.

Amortegui, L. S., Almendros, J. A. C., Medina, R., \& Gala, M. G. (2019). Sustainability and Competitiveness in the Tourism Industry and Tourist Destinations: A Bibliometric Study. Sustainability (Switzerland), 11(6351), 1-30. https://doi.org/10.3390/su11226351

Anwar, F. (2021, April). Update Corona 7 April: Tambah 4.860 Kasus Baru, Total Kasus Aktif 113.570. detik.cometik.com.

Ayittey, F. K., Ayittey, M. K., Chiwero, N. B., Kamasah, J. S., \& Dzuvor, C. (2020). Economic Impacts of Wuhan 2019-nCoV on China and the World. Journal of Medical Virology, 92(5), 473-475. https://doi.org/10.1002/jmv.25706

Bakar, N. A., \& Rosbi, S. (2020). Effect of Coronavirus Disease (COVID-19) to Tourism Industry. International Journal of Advanced Engineering Research and Science, 7(4), 189-193. https://doi.org/10.22161/ijaers.74.23

Budiyanti, E. (2020). Dampak Virus Corona Terhadap Sektor Perdagangan Dan Pariwisata Indonesia. Info Singkat, XII(4), 19-24.

Jurnal Socius: Journal of Sociology Research and Education Vol. 8, No. 2, Th. 2021 
Burchell, G., Gordon, C., \& Miller, P. (1991). The Foucault Effect: Studies in Governmentality. In International Encyclopedia of the Social \& Behavioral Sciences: Second Edition (1st ed.). Chicago: The University of Chicago Press. https://doi.org/10.1016/B978-0-08-0970868.12196-8

Creswell, J. W. (2007). Qualitative Inquiry \& Research Design: Choosing Among Five Approaches. In Sage Publications (Second Edi). University of Nebraska.

Foucault, M. (2008). The Birth of Biopolitics. In M. Senellart (Ed.), The Birth of Biopolitics. Palgrave Macmillan. https://doi.org/10.1057/9780230594180

Gunagama, M. G., Naurah, Y. R., \& Prabono, A. E. P. (2020). Pariwisata Pascapandemi: Pelajaran Penting dan Prospek Pengembangan. LOSARI: Jurnal Arsitektur Kota Dan Pemukiman, 5(2), 56-68. https://doi.org/10.33096/losari.v5i2.76

Herdiana, D. (2020). Rekomendasi Kebijakan Pemulihan Pariwisata Pasca Wabah Corona Virus Disease 2019 (Covid-19) di Kota Bandung. Jurnal Master Pariwisata (JUMPA), 7(1), 1-30. https://doi.org/10.24843/jumpa.2020.v07.i01.p01

Hoque, A., Hasanat, M. W., Shikha, F. A., \& Arif, I. (2020). The Effect of Coronavirus (COVID19 ) in the Tourism Industry in China. Asian Journal of Multidisciplinary Studies, 3(1), 1-7. Indraningsih, G. . K. A. (2019). Implementasi Kebijakan Pembangunan Pariwisata Kota Palu. Jurnal Pariwisata PaRAMA, 1(1), 31-40.

Jessen, M. H., \& Eggers, N. Von. (2020). Governmentality and Statification: Towards a Foucauldian Theory of the State. https://doi.org/10.1177/0263276419849099

Miles, M. B., \& Huberman, A. M. (1994). Qualitative Data Analysis. SAGE Publication.

Mujiono, D. I. K. (2018). Potensi Bahari Pulau Derawan Menuju Destinasi Wisata Kompetitif. Jurnal Dinamika Global, 3(02), 55-87. https://doi.org/10.36859/jdg.v3i02.76

Nugroho, H. (1997). Industrialisasi Sektor Pariwisata: Pintu Masuk Pembangunan atau Pelembagaan Keterbelakangan? Jurnal I-Lib UGM, 16(VI), 28-38.

Pemkab Berau. (2018). Laporan Keterangan Pertanggung Jawaban (Lkpj) Perangkat Daerah.

Pillai, R. (2011). Benefit of Tourism to Local Community: Result or Residue? Indian J. of Tourism \& Hospitality Management, 2(2), 149-161.

Pitana, I. G., \& Diarta, I. K. S. (2009). Pengantar Ilmu Pariwisata. Yogyakarta: CV. Andi Offect. Primadany, S. R., Mardiyono, \& Riyanto. (2013). Analisis Strategi Pengembangan Pariwisata Daerah (Studi pada Dinas Kebudayaan dan Pariwisata Daerah Kabupaten Nganjuk). Jurnal Administrasi Publik (JAP), 1(4), 135-143.

ProKaltim. (2020). Imbas Covid-19, Kunjungan Wisatawan Menurun. Berau, Kalimantan Timur, Indonesia: Kaltim Post. KaltimPost.

Robert, R., \& Tobi, H. B. (2004). Pengantar Sosiologi Kewarganegaraan: Dari Marx Sampai Agamben. Jakarta: Marjin Kiri.

Scott, J. C. (2000). Senjatanya Orang-Orang yang Kalah. Jakarta: Yayasan Obor Indonesia.

Setiawan, I. (2015). Potensi Destinasi Wisata Di Indonesia Menuju Kemandirian Ekonomi. Prosiding Seminar Nasional Multi Disiplin Ilmu\&Call for Papers Unisbank (Sendi_U), 53(9), 1689-1699.

Sofronov, B. (2018). The Development Of The Travel And Tourism Industry In The World. Annals of Spiru Haret University. Economic Series, 18(4), 123-137. https://doi.org/https://doi.org/10.26458/1848 Abstract

Jurnal Socius: Journal of Sociology Research and Education Vol. 8, No. 2, Th. 2021 
Syafrida, S., \& Hartati, R. (2020). Bersama Melawan Virus Covid 19 di Indonesia. SALAM: Jurnal Sosial Dan Budaya Syar-I, 7(6), 495-508. https://doi.org/10.15408/sjsbs.v7i6.15325

Walakula, Y. B. (2020). Analisis Eksistensi Pariwisata Indonesia di Tengah Situasi Pandemi Corona Virus Disease (Covid19). NOUMENA: Ilmu Sosial Keagamaan, I(1), 47-52. 